\title{
Konsep Waktu: Perspektif Komunikasi, Islam, dan Anak TK
}

\author{
Rini Rinawati
}

\begin{abstract}
As pointed out by Dedy Mulyana, a scholar of communication science in Indonesia, communication act is definitely time-bounded. It was expressed in terms su:ch as "wasting time", "saving time", or verbatim such as "time is money", "al-Waktu ka al-syaif", etc. To explain more about time, Edward T. Hall uses Mandala model which describe time in terms of : biological time, personal time, physical time, metaphysical time, micro time, sync time, sacred time, profane time, and meta-time. There are two concepts of time, e.g. monochromic time and polychromic time. As consequences, communication message must be time-sensitive and designed specifically for communication receiver. This article explores time concept of children, and Islamic concept for Islam, which is uniquely defined and different with other time-concept.
\end{abstract}

Kata kunci: waktu, komunikasi, konsep waktu anak-anak, konsep waktu Islam

\section{Pendahuluan}

Komunikasi terjadi dalam konteks ruang dan waktu. Demikian salah satu prinsip komunikasi (Mulyana, 2001). Menarik untuk mengungkap waktu. Beberapa contoh ungkapan sederhana yang sering terdengar dalam keseharian, misalnya, adalah "menghemat waktu", "memboros waktu", "membuang-buang waktu", "menyia-nyiakan waktu", dan lain-lain. Atau juga p e p a t a h, seperti " time is money", "al-Waktu ka al-syaif", dan lainnya. Apa sebenarnya waktu, serta bagaimana manusia memaknainya?

Iwan Fals menjawab pertanyaan mengenai waktu tersebut dalam bait lagunya yang mengatakan "tergilas oleh waktu yang sombong", sementara Einstein (Mulyana,2004a) mengatakan bahwa "waktu tidak mempunyai eksistensi yang independen dari tata kejadian yang memungkinkan kita mengukurnya."

Perbedaan konsepsi waktu, perwaktuan, dan tempo khusus dari kelompok-kelompok budaya merupakan dimensi komunikasi antarbudaya. Walaupun dimensi waktu telah diakui dalam komunikasi antarbudaya, baru sedikit sarjana komunikasi yang telah berusaha menelaah masalah kompleks berupa pemberian perilaku temporal atau penelaahan hal mengenai waktu. Akibatnya, sedikit sekali yang diketahui tentang waktu sebagai variabel penting yang mendasari semua situasi komunikasi interkultural.

Waktu memang merupakan komponen penting dalam komunikasi. Waktu (pagi, siang, sore, dan malam) akan memberikan makna yang berbeda terhadap suatu pesan, yang pada gilirannya tentu akan memberikan reaksi yang berbeda pula pada perilaku yang ditampilkan dalam proses komunikasi tersebut. Ketika mendengar telepon berdering pada tengah malam, maka akan dimaknai sebagai pesan penting (darurat), apakah ada berita kecelakaan atau kematian. Begitu pun ketika 
melihat seorang wanita yang masih berjalan-jalan di malam hari, akan dimaknai sebagai perempuan nakal.

Manusia sebagai animal symbolicum meminjam, istilah Ernst Cassier (Mulyana, 2001), tentunya akan selalu memersepsi sesuatu sebagai sebuah pesan (symbol) terhadap segala perilaku yang ditampilkan oleh manusia yang lainnya. Pada gilirannya, perilaku yang ditampilkan oleh manusia juga akan dipengaruhi konsepsi manusia tersebut terhadap waktu.

Berdasarkan penjelasan di atas, menarik untuk mengkaji konsep waktu dalam kehidupan manusia sehari-hari. Oleh karena itu dalam makalah sederhana ini, akan dikaji "Bagaimana manusia memahami mengenai konsep waktu dalam kehidupan sehari-hari?'
2004), seorang antropolog dan ahli komunikasi yang begitu intent mempelajari waktu yang dianut oleh berbagai budaya, menjelaskan konsep waktu melalui model Mandala. Model ini merupakan suatu model tua mengenai jenis waktu yang berbentuk segi empat dan bertujuan untuk menguraikan hubungan antara berbagai gagasan dengan cara yang komprehensif dan nonlinier.

Hall menjelaskan bahwa waktu itu terdapat dalam delapan konsep yang berlainan, yang bisa diklasifikasikan lagi dalam empat pasang waktu. Terdapat satu kosep waktu di tengah-tengah yang menjadi pusatnya. Kemudian, menurut Hall, adalah keliru untuk memahami konsep waktu yang diterapka pada konsep waktu yang lain. Untuk lebih jelasnya dapat dilihat pada Gambar 1.

G a m b a r 1

W aktu dan kom unikasi

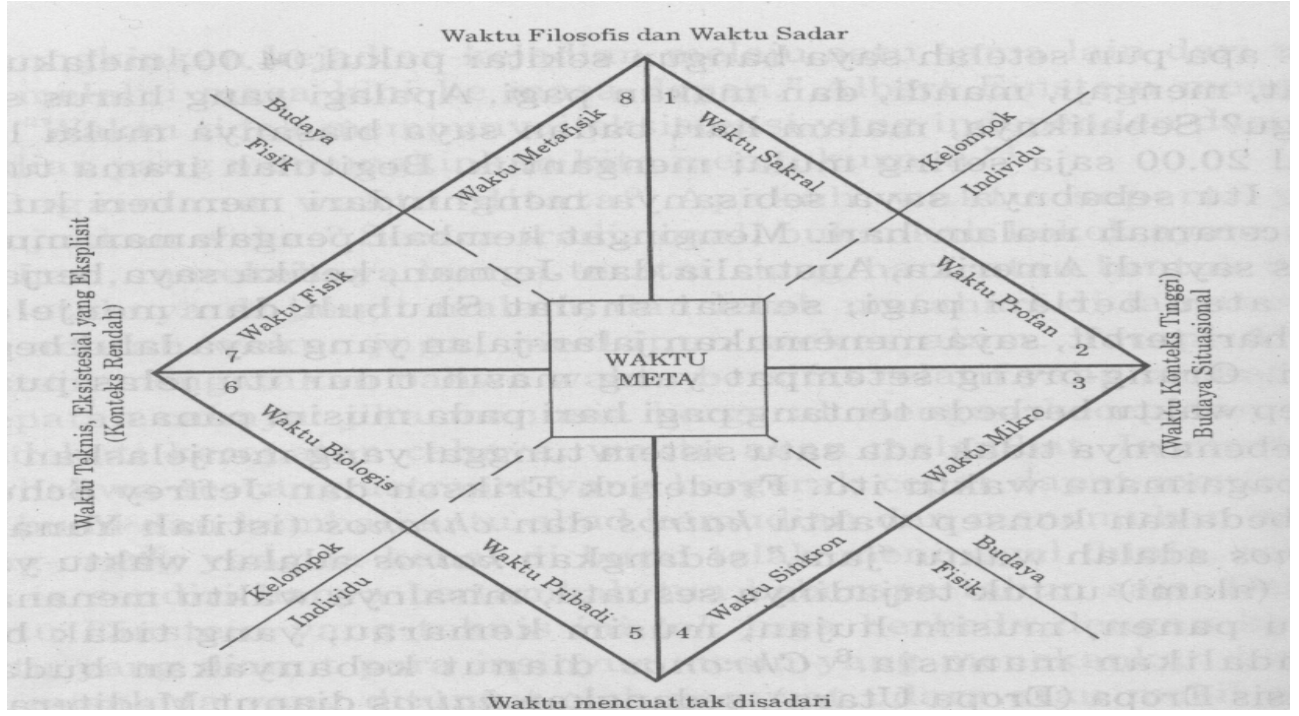

Sum ber: Mulyana, Deddy. 2004. Komunikasi Efektif;

Suatu Pendekatan Lintasbudaya B andung, Remadja Rosdakarya.

\section{Tinjauan Pustaka}

\subsection{Berbagai Jenis Konsep Waktu}

Apa dan bagaimana waktu, sebenarnya belum ada sistem yang dapat menjelaskan secara komprehensif. Edward T. Hall (dalam Mulyana,
Mulyana (2004; 256-260) menjelaskan pengertian konsep waktu yang dimaksud oleh Edward T. Hall dalam model Mandala sebagai berikut: (1) Waktu biologis (biological time), adalah waktu alami yang pada saat ini ditunjukkan oleh weker atau jam, yang secara alami identik 
dengan irama alam seperti usia alam semesta, peredaran planet, usia manusia, pergantian musim, dll. Dengan demikian, waktu biologis merupakan waktu yang sejalan dengan siklus kehidupan.

(2) Waktu pribadi (personal time), adalah waktu yang mengisyaratkan pengalaman setiap orang yang bergantung pada situasi, konteks, aktivitas, serta keadaan fisiologis dan emosi orang tersebut.

(3) Waktu fisik (physical time), adalah konsep waktu alami yang diramalkan atau diukur untuk tujuan-tujuan pragmatis dan ilmiah, seperti meramalkan waktu jatuhnya 1 Ramadhan sebagai awal puasa atau juga 1 Syawal yang menjadi hari Raya Iedul Fitri. Waktu kapan terjadinya musim hujan atau musim kemarau, dll.

(4) Waktu metafisik (metaphisical time), adalah sejenis waktu pribadi, akan tetapi lebih subjektif lagi dan sulit dijelaskan secara konsep, karena lebih menuju pada hal-hal yang ghaib seperti ketika seseorang yang katanya bertemu dengan jin, berkomunikasi dengan orang yang sudah meninggal, dsb.

(5) Waktu mikro (micro time), adalah waktu yang dipengaruhi atau terikat oleh budaya primer, yang aturan-aturannya hampir seluruhnya di luar kesadaran. Konsep waktu monokronik (M) dan konsep waktu polikronik (P) merupakan dua pola waktu yang ada pada waktu mikro ini.

(6) Waktu sinkron (sync time), adalah waktu mensinkronisasikan dengan berbagai situasi dan kondisi, emosi, dan sebagainya. Contohnya adalah bagaimana waktu atau jadwal kegiatan dan waktu tidur ibu yang baru melahirkan dengan bayi yang dilahirkannya.

(7) Waktu sakral (sacred time), adalah waktu atau saat yang bersifat imajiner dan sakral, seperti malam lailatul qadar, Iedul Adha, dsb.

(8) Waktu profan (profan time), adalah waktu yang secara ekplisit dibicarakan dan dirumuskan. Waktu profan ditandai dengan jam, hari, minggu, bulan, tahun, dekade, abad, dan milenimum. Pada sistem waktu profan dan sakral akan saling melengkapi. Orang Islam akan segera menguburkan jenazah, dan tidak mungkin menunda sampai berhari-hari seperti halnya orang Kristen.

(9) Waktu meta (meta time), adalah definisi, konsep, model, atau teori tentang waktu dan sifat-sifatnya seperti yang dikemukakan dan ditulis oleh filosof, agamawan, ahli komunikasi, dll. Oleh karena itu, waktu meta bukan waktu yang sebenarnya, melainan waktu yang diabstrasikan dari berbagai peristiwa waktu. Selanjutnya Edward T. Hall (dalam Mulyana, 2004; 264-274), membedakan konsep waktu menjadi dua, yaitu: pertama, waktu monokronik (M) yaitu mempersepsi waktu sebagai berjalan lurus dari masa silam ke masa depan dan memperlakukannya sebagai entitas yang nyata dan bisa dipilah-pilah, dihabiskan, dibuang, dihemat, dipinjam, dibagi, hilang atau bahkan dibunuh, sehingga waktu tidak pernah kembali. Konsep waktu M ini dianut oleh budaya-budaya barat (Eropa Barat, Skandinavia, dan Amerika Utara.

Para penganut konsep waktu ini menekankan pada penjadwalan dan kesegeraan waktu. Penganut waktu $\mathrm{M}$ cenderung lebih menghargai waktu, tepat waktu, serta menepati jadwal waktu secara ketat. Lihatlah bagaimana orang Jepang yang selalu berjalan dengan cepat. Kita dapat melihat bagaimana supir bus di Australia yang akan tetap berangkat sesuai dengan jadwal keberangkatan sekalipun penumpangnya hanya dua orang, satu orang, bahkan tidak ada penumpang sekalipun.

Konsep "efisiensi waktu" menjadi ciri khas dari penganut konsep waktu M ini. Bagi mereka, waktu adalah uang (time is money). Oleh karena itu, penganut konsep waktu $\mathrm{M}$ ini akan berusaha untuk memperoleh penghasilan yang sebanyakbanyaknya dengan menghabiskan waktu yang sesingkat-singkatnya.

Kedua, waktu polikronik (P) yaitu memandang waktu sebagai suatu putaran yang kembali dan kembali lagi. Menurut penganut waktu P, waktu dapat didaur ulang. Konsep waktu P ini dianut oleh budaya-budaya Timur, budaya Arab, dan budaya-budaya yang tradisional lainnya 
seperti Indian Amerika, dan budaya Afrika. Bagi penganut waktu-P, waktu tidak menjadi kaku seperti yang dipersepsi oleh budaya waktu monokronik yang harus dipenggal-penggal.

Sebagai waktu yang dapat didaur ulang dan merupakan putaran, maka penganut polikronik akan menganggap bahwa waktu itu akan kembali. Inilah yang menjadikan penganut waktu polikronik tidak menghargai waktu. Bagi mereka, ketika sesuatu kesempatan terlewatkan, maka mereka tenang-tenang saja "toh kesempatan itu akan datang lagi di kemudian hari," demikian falsafatnya orang polikronik.

Di samping melalaikan waktu, maka salah satu ciri lainnya dari penganut waktu polikronik adalah tidak adanya rencana kegiatan yang terjadwal secara ketat. Penganut polikronik seringkali punya anggapan "bagaimana nanti" dan bukannya "nanti bagaimana?" Ini memperlihatkan bahwa kegiatan yang dilakukan itu bak air mengalir yang mengikuti aliran sungai, dan tidak memerlukan batasan yang ketat, toh masih ada hari esok.

Berdasarkan penjelasan di atas, maka ciri dari konsep waktu monokronik dan konsep waktu polikronik dapat dilihat pada Bagan 1. meliputi kegiatan bioritmis, keteratunan hormonal dan metabolis, impuls energis (Cattell 1957, 1965); meliputi pengurangan tegangan kebutuhan fisiologis, pola tegangan kebutuhan; dan sebagainya. Petunjuk waktu (temporal signals) berkenaan dengan penginderaan awal dan mendeteksi dorongan waktu sendiri dan dorongan waktu orang lain. Sinyal waktu (temporal signals) meliputi penentuan keberlangsungan perseptual dan interval yang menimbulkan indera waktu individual; kontinuitas dan diskontinuitas yang menimbulkan pengenalan urutan dan keberlangsungan - yang menjadi kebiasaan atau berubah-ubah; fenomena keberlangsungan dan proses yang membentuk informasi perseptual berkenaan dengan pengaturan tempo, pengendalian, pengaturan, atau fasilitasi perilaku manusia; bekenaan dengan pengenalan karakteristik waktu dan perilaku nonverbal.

Perkiraan waktu (temporal estimates): berkenaan dengan indera waktu dan perwaktuan; penggunaan sinyal waktu untuk membuat, mempertahankan, atau mengubah pengenalan sejauh mana kecepatan atau kelambatan waktu mengalir dalam hubungan dengan dasar waktu

\section{Bagan 1 \\ Perbedaan waktu monokronik dengan polikronik}

\begin{tabular}{|l|l|}
\hline \multicolumn{1}{|c|}{ KONSEP WAKTU MONOKRONIK } & \multicolumn{1}{c|}{ KONSEP WAKTU POLIKRONIK } \\
\hline 1. Menganggap waktu berjalan lurus (linier) & 1. Mengangap waktu berjalan berputar \\
2. Waktu menjadi tidak bisa kembali & 2. Masih ada hari esok (waktu dapat kembali) \\
3. Menghargai waktu,dan menepati waktu & 3. Tidak menghargai waktu, dan longgar dengan waktu. \\
$\begin{array}{l}\text { 4. Lebih mementingkan pekerjaan/tugas } \\
\text { (berorientasi tindakan). }\end{array}$ & $\begin{array}{l}\text { 4. Lebih mementingkan hubungan. } \\
\text { 5. Pengambilan keputusan sangat lama (hrs melewati } \\
\text { 5roses yang panjang). }\end{array}$ \\
& \\
\hline
\end{tabular}

\subsection{Taksonomi Lingkungan Waktu}

Taksonomi dapat digunakan untuk menganalisis dan menelaah perilaku waktu dan lingkungan waktu dari berbagai bentuk interaksi manusia. Dorongan waktu (temporal drives) yang personal dan habitual atau standar waktu yang objektif; perkiraan mengenai tingkat tempo yang personal dan atau tingkat peristiwa perilaku.

Lambang waktu (temporal symbols): berkenaan dengan gambaran simbolik urutan dan keberlangsungan, perubahan dan kepermanenan, 
atau perspektif dan orientasi waktu; konsep tempo subjektif dan objektif; berkenaan dengan waktu, perwaktuan dan waktu-waktu objektif; berkenaan dengan fungsionalisasi dan gambaran linguistik yang berkaitan dengan tingkat pengalaman waktu dan seluruh perilaku (termasuk mental).

Kepercayaan waktu (temporal beliefs): berkenaan dengan asumsi-asumsi yang diterima orang sehubungan dengan sifat waktu dan ruang; berkenaan dengan tingkat kekakuan dalam mempersepsi dan mengonseptualisasi perilaku ruang-waktu; mengenai validitas petunjuk dan perkiraan waktu; mengenai validitas informasi waktu yang timbul dan dorongan waktu, sinyal waktu, dan simbolisme waktu; berkenaan dengan validitas dan sifat penilaian waktu dan seterusnya.

Motif waktu (temporal motives): berkenaan dengan maksud psikologis untuk mempengaruhi perilaku waktu; mengenai proses mengubah tempo objektif dan personal; mengenai upaya mempengaruhi dorongan, keperluan, dan motivasi; maksud yang berkaitan dengan tujuan dan perilaku tujuan.

Penilaian waktu (temporal judgments): berkenaan dengan validitas kepercayaan waktu, motif waktu dan nilai waktu (lihat di bawah) seperti yang dijalankan individu atau kelompok individu dalam konteks sosiokultural.

Nilai waktu (temporal values): mengenai pemberian nilai pada waktu, waktu-waktu (peristiwa), dan perwaktuan ketika dikaitkan dengan perilaku personal, sosial, dan kultural.

\section{Pembahasan}

Edward T. Hall (dalam Mulyana, 2004a; 251) menyatakan bahwa waktu menjadi penting dalam proses komunikasi khususnya komunikasi antarbudaya. Setiap budaya mempunyai konsep waktu yang berbeda. Bahkan Oswald Spengler (dalam Mulyana, 1998;122) menyatakan bahwa "makna yang secara intuitif diterapkan pada waktulah yang menyebabkan satu budaya dibedakan dari budaya yang lain." Oleh karenanya, seringkali konsep terhadap waktu sebagai penanda budaya dibedakan antara konsep waktu budaya barat dengan konsep waktu budaya timur. Pada gilirannya, dalam setiap kelompok besar budaya tersebut, terdapat aspek-aspek yang berbeda antara satu negara dengan negara yang lain, seperti dalam kelompok budaya timur antara Indonesia dengan Jepang, atau dalam kelompok budaya barat antara Amerika dengan Meksiko, dsb.

Pandangan bahwa temporalitas (ihwal waktu) satu budaya lebih baik dari temporalitas budaya yang lain tampak sebagai dasar utama persepsi antarbudaya terhadap inferioritas dan superioritas. Jarang sekali orang mengakui bahwa persepsinya tentang orang dan budaya yang lain ada hubungannya dengan elitisme atau kekakuan akan orientasi waktu kultural mereka sendiri. Orang sering membandingkan orientasi waktu mereka dengan orientasi waktu kelompok budaya yang lain.

Pada beberapa kebudayaan, berkomunikasi sangat ketat dalam penggunaan waktu. Orang Amerika mempunyai konsep waktu adalah uang (time is money). Bagi orang Amerika, waktu dianggap sebagai komoditas yang berharga untuk menghasilkan uang, sehingga mereka tidak dapat berleha-leha. Orang-orang Amerika sangat menghargai waktu, sehingga menjadi orang yang tepat waktu. Sebaliknya, bahasa Indonesia tidak mempelihatkan keketatan dalam penggunaan waktu. Sering terdengar, orang Indonesia berkata mengenai kebiasaan terlambatnya; "maaf saya datang agak terlambat" (padahal keterlambatan sudah lebih dari 30 menit). Budaya "jam karet" yang dianut Indonesia menyebabkan undangan, misalnya, menjadi dibuat 30 menit lebih awal, sebagai antisipasi keterlambatan yang sudah membudaya. Maka, bangsa Indonesia sering kehilangan kesempatan memenangkan sebuah pekerjaan, hanya karena datang terlambat.

Contoh ini menunjukkan bahwa persepsi tentang waktu akan mengakar pada kebudayaan di mana individu berada. Konsep waktu menjadi penanda bagi suatu budaya. Dengan beragamnya kebudayaan yang ada, maka beragam pula persepsi mengenai konsep waktu. Pada gilirannya persepsi tentang waktu merupakan persepsi psikologis yang bergantung pada peristiwa, latar, situasi dan kondisi dari pesan yang disampaikan. Yang paling 
menarik adalah bahwa fakta konsep waktu ini telah diungkapkan kepada umat manusia dalam alQur'an sejak empat belas abad yang lalu. Ada berbagai referensi dalam al-Qur'an mengenai relativitas waktu ini. Sebagai contoh, seluruh kehidupan seseorang sangat singkat seperti yang dikabarkan dalam al-Qur'an:

"Dan (ingatlah) akan hari (yang di waktu itu) Allah mengumpulkan mereka, (mereka merasa di hari itu) seakan-akan mereka tidak pernah berdiam (di dunia) kecuali hanya sesaat saja di siang hari (di waktu itu) mereka saling berkenalan. Sesungguhnya rugilah orang-orang yang mendustakan pertemuan mereka dengan Allah dan mereka tidak mendapat petunjuk" (QS. Yunus [10]: 45).

Suatu kajian tentang konsep waktu pun menjadi studi khusus yang dinamakan kronemika (chronemic), yaitu suatu studi atau interpretasi atas waktu sebagai pesan. Dengan demikian, bagaimana seseorang memperlakukan atau menganggap waktu dalam kehidupan ini akan menjadi pesan siapa diri orang tersebut. Sebagai contoh, bila kita melihat seseorang datang terlambat dalam sebuah pertemuan, kita menjadi tahu bahwa orang tersebut dari Indonesia. Hal ini dikarenakan budaya jam karet yang sudah membudaya di masyarakat Indonesia. Kebiasaan jam karet masyarakat Indonesia bahkan menjadi sebuah lelucon (Mulyana. 2001;370) sebagai berikut:

Sebuah seminar yang diselenggarakan di Cambera, Australia diikuti banyak negara, termasuk Indonesia dan Thailand. Wakil dari Thailand terlihat berlarilari menuju tempat pendaftaran ulang anggota seminar karena sudah terlambat. Sambil terengah-engah, ia menandatangani daftar hadir, tetapi kemudian ia tersenyum sendiri dengan penuh rasa bangga melihat keanehan yang terjadi, seorang petugas berkata, “Ada apa sampai anda tersenyum sendiri?" Ia menjawab, "Ternyata Thailand selangkah lebih maju dari Indonesia".

Perbedaan konsepsi terhadap waktu pada gilirannya tidak hanya terjadi pada budaya-budaya, tetapi juga akan terjadi pada diri individu masingmasing, sekalipun dalam kebudayaan yang sama. Hal ini dikarenakan pada dasarnya manusia sebagai individu adalah unik (berbeda satu sama lain). Beberapa contoh konsep waktu yang dipahami oleh manusia, yang mana menjadi faktor penentu dalam kegiatan keseharian dapat kita lihat pada beberapa contoh berikut ini.

\subsection{Konsep Waktu dalam Agama Islam}

Konsepsi waktu bagi umat Islam, sebetulnya, sudah secara digambarkan dan dijelaskan dalam Al-Quran dan Hadits. Al-Quran dalam menjelaskan dan menunjuk suatu masa tertentu yang lazim disebut "waktu" dilakukan dengan dua cara penyebutan yaitu waktu yang bersifat umum dan waktu yang dibatasi. Istilah tentang waktu dalam al-Quran adalah:

(1) Ad-Dahr: digunakan untuk menjelaskan masa yang panjang dan lama yang dilalui oleh alam raya dalam kehidupan, yakni sejak diciptakan sampai punah.Istilah ini memberikan pemahaman bahwa segala sesuatu itu pernah tiada dan akan tiada kembali. Artinya, keberadaannya menjadi terikat oleh waktu. Contohnya, keberadaan manusia dan semesta alam raya ini. Istilah ini ada dalam QS Al-Jasiah ayat 24, dan QS Al-Insan ayat 1 .

(2) Ajal: yaitu nama yang digunakan untuk menjelaskan masa tertentu yang ditetapkan bagi sesuatu. Kata ini bisa digunakan untuk menunjuk waktu berakhirnya sesuatu, seperti berakhirnya usia manusia dan masyarakat. Dengan demikian kata 'ajal' menjelaskan bahwa segala sesuatu ada batas waktu berakhirnya sehingga tidak ada yang langgeng, kecuali Dzat Allah SWT. Kata ini terdapat dalam:

(a) Quran Surat Al-Munafikun ayat 9-10

(b) Quran Surat Yunus ayat 49

(c) Quran Surat Al-Imran ayat 145

(d) Quran Surat Al-ar'af ayat 34

(e) Quran Surat Al-Hijr ayat 5.

(3) Al-Waktu: kata ini biasa digunakan untuk memberi arti batas akhir kesempatan atau peluang untuk menyelesaikan suatu kegiatan, karena itu Al-Quran seringkali menggunakan kata Al-Waktu ini untuk menjelaskan kontek 
kadar tertentu dari suatu massa. Kata ini menghendaki adanya keharusan untuk pembagian teknis mengenai massa yang dialami seperti detik, menit, jam, hari, minggu, bulan, dan tahunan. Kata ini terdapat dalam:
(a) Quran Surat Al-Hajr ayat 38
(b) Quran Surat Al-A 'raf ayat 187
(c) Quran Surat An-Nisa ayat 103
(d) Quran Surat Al-Baqarah ayat 189

(4) Al-Ashr: kata ini digunakan untuk menjelaskan waktu menjelang terbenamnya matahari. Namun, kata ini juga digunakan untuk menjelaskan masa secara mutlak. Kata ini terdapat dalam Q.S. Al-Ashr ayat 1.

Melihat pada penggunaan beberapa istilah atau kata untuk menjelaskan konsep waktu yang ada dalam Al-Quran, maka sebetulnya Islam adalah agama yang begitu mementingkan waktu. Dengan demikian, sebetulnya Islam menganut konsep monokronik, yang menganggap waktu terus berjalan secara linier dan tidak biasa berputar ulang. Islam memiliki lima waktu dalam keseharian untuk menjalankan kegiatan shalat yang jelas batasan awal dan berakhirnya waktu shalat. Bagi umat Islam, segala kegiatan (khususnya ibadah) terikat waktu, artinya ada batasan pelaksanaannya. Di luar waktu itu, kegiatan tidak bisa dilaksanakan. Contoh: zakat, puasa, ibadah haji, akikah, dll.

Untuk menunjukkan pentingnya waktu, Allah SWT bersumpah dalam beberapa surat Al-Quran dengan menggunakan waktu, seperti:

(a) Surat Al-Lail ayat 1-2 (wallaili, yaitu demi waktu malam),

(b) Surat Al-fajr ayat 1-2 (walfajri, yaitu demi waktu fajar),

(c) Surat Adh-Duha ayat 1-2 (wadhuha, yaitu demi waktu duha atau pagi),

(d) Surat Al-Ashr ayat 1-2 (walashri, yaitu demi waktu ash).

Di samping Al-Quran yang menjelaskan pentingnya waktu, Sunnah Rasulullah telah memperkuat adanya nilai pentingnya waktu dan menetapkan pertanggungjawaban manusia tentang penggunaan waktu dihadapan Allah SWT.
Rasulullah SAW bersabda: "Kedua kaki hamba pada hari kiamat tidak akan bergeser dari tempatnya, sebelum kepadanya diajukan empat pertanyaan:

(a) Tentang umurnya dihabiskan untuk apa.

(b) Tentang fisiknya (masa mudanya) digunakan untuk apa

(c) Tentang hartanya darimana diperolehnya dan untuk apa dipergunakannya

(d) Tentang ilmunya dimanfaatkan untuk apa." (H.R. Bazar dan Tabrany)

Hadits di atas memperlihatkan bahwa bagi orang Islam, waktu hidup akan diperhitungkan nanti di alam akhirat, sehingga penggunaan waktu dengan perencanaan yang matang dan jelas menjadi satu keharusan. Dalam hadits lain, Rasulullah SAW bersabda: "Jagalah lima perkara sebelum datangnya lima perkara yang lain. Yaitu:

(a) Masa mudamu sebelum datangnya masa tuamu,

(b) Masa sehatmu sebelum datang masa sakitmu,

(c) Masa kayamu sebelum datang masa miskinmu,

(d) Masa hidupmu sebelum datang masa matimu,

(e) Masa luangmu sebelum datangnya masa sibukmu. (H.R. Hakim dari Ibnu Abbas)

Umat Islam dalam berperilaku, seyogyanya mengikuti apa yang telah diatur dalam pedoman hidupnya, yaitu Al-Quran dan Hadits tersebut. Melihat pada konsepsi yang dipunyai oleh agama Islam, maka agama Islam memberikan pedoman hidup yang sesuai dengan waktu monokronik, yang menganggap waktu sebagai berjalan lurus dari masa silam ke masa depan dan memperlakukannya sebagai entitas yang nyata dan bisa dipilah-pilah, dihabiskan, dibuang, dihemat, dipinjam, dibagi, hilang, atau bahkan dibunuh, sehingga waktu tidak pernah kembali.

Bagaimana perjalanan hidup manusia menurut Islam. Dimulai dari tidak ada, kemudian ditempatkanlah oleh Allah seseorang pada perut seorang ibu yang dikenal dengan alam rahim. Setelah itu, manusia akan memasuki alam dunia yang harus diisi dengan segala perbuatan amal shaleh, karena bagi Islam, kematian bukan akhir dari kehidupan. Perjalanan orang Islam akan 
diteruskan sekalipun kematian sudah dilalui. Bagi orang Islam, ada alam kubur yang menjadi tempat peristirahatan sebelum masuk pada alam mahsyar, yang diteruskan pada alam akhirat (penghisaban) yang merupakan alam yang kekal.

Dengan demikian, perjalanan yang lurus dan linier ini seharusnya menjadikan umat Islam sebagai orang yang menghargai waktu dan berdisiplin dengan waktu sebagaimana konsepsi monokronik, dan menjadikan kosepsi waktu ini sebagai kebiasaan (budaya) dalam berperilaku kesehariannya. Berbagai pelaksanaan ibadah, yang merupakan kewajiban bagi umat Islam, sebetulnya menjadi salah satu ciri kedisiplinan tentang waktu dan harus menjadikan kebiasaan. Tidak mungkin kita shalat subuh diwaktu ashar; sama tidak mungkinnya kita melaksananakan perjalanan haji di luar bulan Dzulhijjah, atau membayar zakat fitrah setelah Iedul Fitri.

Namun, kenyataannya, kebiasaan disiplin dan menghargai waktu ini tidak tercermin pada pribadi orang Islam di Indonesia. Masih banyak orang Islam yang tidak menghargai waktu, bahkan tidak disiplin dengan waktu. Saat perjumpaan dengan Allah SWT saja (shalat) seringkali kita menundanundanya atau lebih mementingkan urusan duniawi, sehingga shalat dilakukan selalu di akhir waktu.

Agama Islam memang tidak hanya urusan hablunminnallah (beribadah kepada Allah SWT), tetapi juga harus diimbangi dengan habluminnannas (hubungan baik dengan manusia). Inilah, mungkin, salah satu yang memengaruhi pada pergeseran konsep waktu pada orang Islam, karena ternyata orang Islam juga memegang kebudayaan timur dalam rangka berhabluminnannas-nya. Jadilah orang Islam itu banyak yang menganut konsepsi polikronik dalam perilaku kesehariannya.

\subsection{Konsep Waktu pada Anak Kecil (Usia TK)}

Anak seusia TK memunyai cara-cara (budaya) bergaul yang berbeda dengan anak yang lebih besar lagi, bahkan berbeda budayanya dengan $\mathrm{ABG} /$ remaja, dan orangtua.
Perbedaan budaya yang terjadi pada gilirannya akan menyebabkan perbedaan persepsi terhadap konsep waktu, karena seperti kita ketahui bahwa persepsi seseorang terhadap sesuatu (konsep waktu) dipengaruhi oleh budayanya. Persepsi kita tentang waktu merupakan persepsi psikologis yang bergantung pada peristiwa, latar, situasi, dan kondisi dari pesan yang disampaikan. Namun demikian, persepsi terhadap waktu pun ditentukan usia seorang manusia.

Satu contoh menarik dari konsep waktu berdasarkan usia ini adalah ketika anak usia TK begitu bingung dengan waktu-waktu berikut: 'Kemarin', 'kemarin dulu', 'tadi', 'besok lusa', 'sebentar lagi', 'sejam yang lalu', 'tiga hari lagi', 'minggu depan', 'bulan lalu', dan 'tahun depan'. Umumnya, anak seusia TK ini mengalami kesulitan untuk memahami waktu-waktu tersebut.

Sebagai ilustrasi tambahan, berikut disajikan hasil penelitian "kedil-kecilan."

Penelitian singkat ini dilakukan pada sebuah Taman Kanak-Kanak Islam yang bernama TK Islam Al-Bayan beralamat di Margahayuraya Kota Bandung. Data primer kami dapatkan dengan cara wawancara terhadap beberapa orang tua murid yang kebetulan mengantar dan menunggui anaknya. Di samping itu, dilakukan observasi singkat terhadap anak-anak yang sedang bermain untuk melihat bagaimana komunikasi yang dilakukan khususnya mengenai pemahaman tentang waktu.

Penelitian dilakukan selama kurang lebih 3 hari, hal ini dikerarenakan keterbatasan waktu yang dipunyai untuk mengumpulkan dan mengolah data. Di samping itu, kami juga melakukan wawancara singkat dengan ibu gurunya untuk mengetahui bagaimana pemahaman konsep waktu dijelaskan pada anak didiknya.

Hasil penelitian yang dilakukan memperlihatkan beberapa contoh kasus berikut sebagai hasil wawancara kami dengan beberapa orangtua murid TK Islam Al-Bayan, yaitu:

(a) Ada seorang anak yang meminta untuk dibelikan mainan oleh ibunya, terus meminta dan merengek-rengek setiap hari, padahal ibunya sudah menjanjikan akan mengabulkan 
permintaannya dengan sedikit pengunduran waktu melalui kalimat: "nanti ya nak, kalau ibu sudah dapat gaji."

(b) Ada seorang anak TK yang kebingungan tentang PR yang diperuntukan dua hari berikutnya, ia meminta ibunya untuk dikerjakan karena mengira PR tersebut harus dibawa besok hari.

(c) Ada juga contoh kasus, seorang anak yang kesulitan untuk menjelaskan waktu kegiatan yang dilakukan, seperti ' Tadi Jabar dibeliin ibu mobil-mobilan," ujar Jabar, dan ibunya berkata 'Lho, itu kan kemarin.

Dari beberapa contoh kasus tersebut, maka kiranya anak yang masih kecil (usia TK) belum jelas dalam memahami konsep waktu. Bagi mereka waktu seolah tidak ada bedanya; tadi, sekarang, nanti, besok, kemarin adalah sama saja. seorang psikolog anak, menjelaskan bahwa kondisi seperti itu merupakan hal yang wajar pada anak usia TK. Pasalnya, cara berpikir anak usia 4 sampai 6 tahun masih dalam tahap awal atau prakonkret. Bagi anak usia TK, konsep waktu merupakan hal yang sangat abstrak. ' Kata-kata seperti, kemarin, besok, lusa sangat abstrak bagi anak."

Seorang anak, menurut Evita, harus bisa memahami konsep waktu pada usia tujuh tahun. Oleh karena itu, konsep waktu seperti itu sebaiknya diajarkan sejak dini kepada anak. Dengan mengenalkan anak konsep waktu, maka anak akan mampu mengatur waktu (time management) dan lebih berdisiplin dalam menjalani waktu dalam kehidupannnya.

Anak usia dini 1-2 tahun konsep pengaturan waktu berkaitan dengan pembiasaan-pembiasaan. Artinya, anak belum mampu mencapai target tertentu layaknya orang dewasa. Tapi, anak sudah dapat dibiasakan melakukan kegiatan sesuai dengan waktunya, seperti waktu tidur siang, makan, jam tidur malam, dan seterusnya. Bagi anak usia sekolah, barulah anak mengenal konsep waktu dengan belajar menyusun jadwal sehari-hari. "Karena di masa sekolah, anak sudah mulai menjalani kegiatan formal dengan waktu yang lebih teratur."
Persoalannya bagaimana mengajarkan konsep waktu pada anak? Dalam hal proses pembelajaran atau pengenalan konsep waktu pada anak TK khususnya TK Besar (kelas B), berbagai cara dilakukan oleh para guru di TK Islam AlBayan yaitu sebagai berikut:

(a) Guru TK Islam Al-Bayan mengajak anak didiknya untuk berkebun di halaman yang telah disediakan. Dari jumlah anak yang ada ( 25 orang), dibuat 5 kelompok yang memunyai tugas untuk membawa tanaman dan menanamnya sendiri serta merawatnya. Dalam berkebun, tentunya, secara tidak langsung ditanamkan konsep waktu. Anak-anak menjadi tahu berapa hari tanamannya itu berbunga, karena si anak mempunyai kewajiban untuk memeliharanya setiap pagi dibantu dengan ibu guru.

(b) Konsep waktu juga diajarkan lewat ceritacerita yang ditayangkan melalui film anakanak. Ibu guru akan menjelaskan mengenai waktu-waktu yang ada dalam cerita tersebut. Dari kegiatan ini, tentunya, kami melihat bahwa ibu gurunya mencoba untuk mengajarkan anak mengenai konsep waktu dan perbedaannya, misalnya, waktu siang itu terang, waktu malam itu gelap, waktu pagi, dsb.

(c) Pembelajaran mengenai konsep waktu juga dilakukan dengan cara terjun lapangan, yaitu melalui metode berbelanja di supermarket terdekat, si anak biasanya disuruh belanja selama 30 menit untuk membeli barang kesayanganya. Dari kegiatan ini, dikenalkan konsep waktu yang sudah spesifik yaitu berdasarkan waktu karena si anak diharuskan melihat jam. Pelaksanaannya biasanya dibantu oleh orangtua siswa.

(d) Membuat jadwal piket, anak-anak untuk membantu ibu guru dalam membereskan ruang belajar. Dari kegiatan ini, si anak dikenalkan dengan konsep hari-hari. Bahkan, pengenalan hari itu dilakukan melalui lagu.

Dengan adanya berbagai cara yang dilakukan tersebut, para guru berharap anak-anak TK Islam Al-Bayan dapat mengenal konsep waktu dan dapat 
mengatur waktu (time management) dan membentuk disiplin diri dan rasa tanggung jawab anak. Konsep waktu tentu saja penting diajarkan. Bahkan, dalam Islam, waktu pun mendapat prioritas dan perhatian utama setelah membaca. Dengan mengenalkan anak konsep waktu, maka anak akan mampu mengatur waktu dan lebih berdisiplin dalam menjalani waktu dalam kehidupannnya.

Apa yang telah dilakukan oleh guru-guru TK Islam Al-Bayan tersebut, sesuai dengan apa yang dikemukakan Evita tentang beberapa cara proses pengajaran konsep waktu pada seorang anak, yaitu:

(a) Anak masih berpikir prakonkret, maka konsep waktu harus diajarkan dengan cara-cara yang konkret, lewat media gambar ataupun mengajak langsung ke lapangan.

(b) Pada anak TK, yang paling awal harus dikenalkan kepada mereka adalah soal pagi, siang dan malam. Lewat gambar, anak bisa diperlihatkan bahwa malam itu biasanya gelap, siang itu terang.

(c) Konsep waktu bisa juga diajarkan dengan bercerita. Orang tua dan guru bisa menceritakan pengalaman nyata dalam mengajarkan anak tentang konsep waktu. Itu perlu dilakukan agar anak tidak bingung. "Tadi malam hujan lebat sekali, kalian pasti tertidur pulas."

(d) Setelah anak mengenal konsep waktu yang sederhana, seperti pagi, siang, dan malam, pada tahap berikutnya bisa diajarkan tentang konsep lama. Misalnya, 'Waktu istirahat hanya 10 menit, kalian bisa main." Setelah itu, "Waktu istirahat sudah habis."

(e) Untuk mengenalkan konsep waktu, maka dalam proses pembelajaran orang tua dan guru harus mengulang ucapannya berkali-kali. Sehingga, anak bisa lebih paham.

(f) Selanjutnya, mengajarkan anak soal konsep waktu bisa disesuaikan dengan aktivitas si anak. Misalnya saja, "Besok kalian tidak sekolah, karena libur.” Itu mengajarkan kepada anak bahwa besok adalah hari libur.

(g) Pada tahap berikutnya, anak bisa diajarkan membaca jam. Ini perlu dilakukan seiring anak mengenal angka. Membaca jam, biasanya mulai dikenalkan pada anak yang berusia tujuh tahun ke atas. Dengan begitu, anak bisa memahami konsep waktu lebih cepat. Dalam mengajarkan konsep waktu, orang tua dituntut untuk sabar dalam memberi penjelasan.

Sebenarnya, seorang anak akan dengan sendirinya mengenal konsep waktu dari hasil pergaulan dengan teman atau lingkungan sekitarnya. Tahap awal pengenalan konsep waktu tentunya akan diperoleh anak dari orang-orang terdekat (significant other). Oleh karena itu, sebaiknya orangtua atau saudara-saudaranya dapat membantu proses pembelajaran anaknya yang usia TK mengenai konsep waktu. Baru setelah itu adalah teman dilingkungan sekitar maupun yang lebih jauh, misalnya yang satu sekolah. Kemudian juga yang memberikan sumbangan dalam pengenalan waktu pada diri anak adalah guru di sekolah.

Dari penelitian yang dilakukan tentang konsep waktu pada anak di TK Islam Al-Bayan, maka kami memeroleh kesimpulan sebagai berikut:

(a) Anak usia TK masih kesulitan dalam memahami konsep waktu. Dengan adanya kesulitan ini, kontribusi orangtua dan guru menjadi sangat penting dalam proses belajar anak mengenal waktu. Oleh karena itu, konsep waktu anak TK akan banyak dipengaruhi bagaimana konsep waktu yang diajarkan oleh orangtua atau guru-gurunya di sekolah. Pada giliranannya, dari konsep waktu yang terbentuk sejak dini inilah akan memengaruhi konsep waktu di kemudian hari (setelah anak berangkat remaja, dan menjadi dewasa). Untuk itu, kami menamakan konsep waktu yang dipunyai anak-anak khususnya usia TK dengan Kiddy Time (looking for Identity kronik), yaitu konsep waktu atau khasanah waktu yang khas pada diri anak. Waktu, dalam konsep ini, dipersepsi sebagai proses pencarian konsep waktu pada diri anak. Proses pembentukan ini akan menuju pada konsep waktu monokronik atau polikronik tergantung proses pembelajaran yang dilakukan oleh anak 
tersebut terhadap lingkungannya yang disesuaikan dengan budaya.

(b) Diperlukan metode pembelajaran yang khusus (seperti berkebun, bercerita, film, terjun ke lapangan) untuk mengenalkan konsep waktu pada anak TK.

\section{Kesimpulan}

Dari penjelasan yang telah dikemukakan mengenai pemahaman konsep waktu yang dilakukan oleh manusia dalam kehidupan sehari hari ternyata terjadi perbedaan baik secara budaya maupun usia. Perbedaan pemahaman mengenai konsep waktu pada gilirannya akan mempengaruhi perilaku yang ditampilkan dalam keseharian manusia tersebut.

\section{Daftar Pustaka}

Devito, A. Joseph. 1997. Komunikasi Antar Manusia; Kuliah Dasar. Terj. Agus Maulana. Jakarta: Professional Books.
Gudykunst, William \& Young Yun Kim. 1992. Communicating With Strangers; An Approach to Intercultural Communication (second edition). New York: McGraw-Hill.

Liliweri, Alo. 2004.Dasar-Dasar Komunikasi Antarbudaya. Yogyakarta: Pustaka Pelajar.

Lewis, Richard D. 1996. Menjadi Manajer Era Global; Kiat Komunikasi Bisnis LintasBudaya. Bandung: Remadja Rosdakarya.

Mulyana, Deddy, \& Jalaluddin Rakhmat. 1996. Komunikasi Antarbudaya. Bandung: Remadja Rosdakarya.

Mulyana, Deddy. 2000. Ilmu Komunikasi: Suatu Pengantar. Bandung: Remadja Rosdakarya.

.2004a. Komunikasi Efektif; Suatu Pendekatan Lintasbudaya. Bandung: Remadja Rosdakarya. . 2004b. Komunikasi Populer: Kajian Komunikasi dan Budaya Kontemporer. Bandung: Pustaka Bani Quraisy. 
